\title{
Anti corruption cases and their application in the course of morality and rule of law
}

\author{
Yanjun Tao" \\ School of politics and public administration of Qingdao University
}

\begin{abstract}
: the middle school stage is a special stage, middle school students' body and heart are in an important stage of development, outlook on life, world outlook, values in the formation stage, in this stage of ideological guidance education is particularly important, the urgent need for schools in the ideological and moral development to give correct guidance and effective help.But our country is in the transformation stage, the corruption problem in the society is gushing, the emergence of corruption problem and the lack of corruption education in the ideological stage of adolescence have an inseparable relationship, this paper analyzes the application of anti-corruption cases in the moral and rule of law class.
\end{abstract}

Keywords: anti corruption cases, morality and rule of law, middle school stage

\section{The background and practical significance of the application of anti-corruption cases in the course of morality and rule of law}

"Emotion, attitude and values" is one of the curriculum properties in the new curriculum standard of morality and rule of law.These three concepts are related to each other and have independent meanings. When emotion and attitude rise to a certain extent, they are called values. Values are a further level of emotion and attitude.The order of the three also reflects the process of students' ideological development.It is a problem for our educators to integrate the cultivation of emotional attitude and values into classroom teaching activities, and cultivate the thought of clean government in the classroom of morality and rule of law. How to achieve this goal is an important topic for educators.

1.1 The characteristics of students' development in junior high school

The development of junior high school students has the following characteristics: students are in the age of 12-16 years old, which is called "juvenile period" by pedagogy and psychology.During this period of time, psychological and physiological changes are relatively rapid, and physical and mental aspects are relatively contradictory.Parents attach great importance to the monitoring and control of this critical and dangerous period.During this period, they were full of energy and curiosity, and always wanted to try anything.Another remarkable feature of this period is the gradual maturity of their physiological development. On the one hand, they feel novel about the development of all parts of their body. On the other hand, they are full of shyness and uneasiness. They are unwilling to let their parents into their own room and have their own secrets.Psychological performance is easy to be excited and impulsive, nervous sensitivity, resulting in the germination of love, most of the puppy love children occur in this period.Impulse is the biggest characteristic of their period, curiosity is the peak of their life.Although they can't distinguish right from wrong, they are confident and have the lowest self-restraint ability during this period.Therefore, parents and teachers must strengthen education and guidance.

1.2 The era background and practical significance of the application of anti corruption cases in the course of morality and rule of law

The states emphasis on corruption has always been the focus of the construction of a clean and honest government of the national leadership, and the ideological construction of the national leadership is also the focus of the states attention. Teenagers are the hope of the country in the future. The education of young people's anti-corruption thought should start from now on, but parents and schools pay more attention to students' physical and psychological changes, pay attention to students' learning and intellectual development, pay attention to students' morality, values, outlook on life and other ideological aspects, but the attention is not enough. Therefore, the education of students' incorruptible thought should start from the classroom of junior middle school.

\section{The application of anti corruption cases in the course of morality and rule of law}

2.1 Promoting the cultivation of emotion, attitude and values through soul collision

It is important to infiltrate the mind collision into the teaching activities of morality and rule of law in junior middle school, extract the emotional factors that can cause the mind collision in the teaching materials, and transform the knowledge, skills,

Copyright (C) 2020 Yanjun Tao

doi: 10.18282/l-e.v9i4.1693

This is an open-access article distributed under the terms of the Creative Commons Attribution Non-Commercial License (http://creativecommons.org/licenses/by-nc/4.0/), which permits unrestricted non-commercial use, distribution, and reproduction in any medium, provided the original work is properly cited. 
process, methods and teaching art into the infiltration of emotional attitude and values.For example, in the lesson of honesty and faithfulness, we focus on letting students feel honesty through stories such as honesty breakfast shop, promise a thousand gold, and standing wood for faith, as well as the true honesty stories around students, so as to cultivate students' habit of thinking about their own life.LuXun said: "since ancient times, there have been people who work hard, who work hard, who ask for the people's life, and who sacrifice their lives to seek the law... Although they are the so-called" official history "that is equal to writing genealogies for emperors and generals, they can not hide their glory. This is the backbone of China." ${ }^{[1]}$ In the 5000 year political history of $\mathrm{t}$ he Chinese nation, a large number of eternal examples have emerged, which are conscientious, patriotic and concerned about the people, honest and trustworthy, honest and upright, and strict in law enforcement. In this way, teachers need to combine the content of teaching materials and take specific ways to carry out teaching, so that the infiltration of emotional attitude and values can be implemented.

Bandura, an American psychologist, pointed out that "if knowledge can only be acquired through the individual's own experience, then the process of cognitive and social development will be greatly delayed, let alone boring." Most human behavior is acquired through the observation of role models. "[2] In the teaching of "morality and rule of law", example teaching also plays an important role.

2.2 Plan teaching situation and make them actively participate in classroom teaching activities

In teaching activities, teachers should be good at creating effective situations, arranging related activities, creating a good atmosphere that can stimulate students' interest in political learning, fully meeting their internal demand for knowledge, so as to make students feel happy. For example, in the class of civil rights and obligations, students are organized to collect information about rights and obligations in groups, and then they are asked to compile the existing materials into short plays or sketches, and perform their roles in the class, so that students can get different emotional experiences from multiple perspectives, and fully feel the value of cherishing power and obligations. When collecting materials, the students used the cases of Xu Caihou, sun Zheng, Su Rong and other officials who had been demoted since the 18th CPC National Congress. By analyzing the corruption and other specific cases of demoted officials, the students deeply felt the great harm of corruption to society and the country. They also strengthened the students' awareness of clean government and developed a correct world outlook and values from childhood.

2.3 Show the power of example and make the thought of clean government go deep into my heart

"We can learn from bronze to correct our clothes; we can learn from ancient times to know the rise and fall; we can learn from people to know the gains and losses." ${ }^{[3]}$ Every incorruptible figure in Chinese history is a banner. These figures are familiar to st udents, respectable and credible.The thought represented by the anti-corruption figures is a real and vivid anti-corruption case, which can be operated and learned, and can be used as a yardstick for the comparative examination of students' thoughts and behaviors. In the teaching of "morality and rule of law", the teacher tells the students about the touching deeds of the incorruptible characters, such as worrying about the country and the people, being diligent and loving the people, abiding by the law, integrating incorruptibility into the government, setting an example, and doing nothing. The teacher infiltrates the concept of incorruptible government into the cultivation of students' emotion, attitude and values, and cultivates students' sense of social responsibility through the examples of incorruptible characters, so as to cultivate students to establish a solid national concept, cultivate students' sense of social responsibility People's view, fairness and justice view, collective view.

Paying attention to the education of clean government culture from the stage of compulsory education is an important way to the construction of social clean government atmosphere. Taking the ideological education of junior high school students as the starting point, attaching importance to the power of example, and combining with the application of anti-corruption cases in the classroom, we can realize the fundamental transformation of the whole social environment, and provide a pure and healthy social environment for our life.In the harmony of theory and practice, ideal and reality, the education of morality and rule of law will have a way out, a breakthrough and innovation

\section{Reference}

[1]Lu Xun. Have the Chinese lost self-confidence [a]. Lu Xun\&apos;s works (6) [C]. Zhengzhou: Zhengzhou University Press, 2004:1775-1776.

[2] A. Bandura. The social basis of thought and action -- social cognition theory (Volume I) [M]. Shanghai: East China Normal University Press, 2001:63

[3] Ouyang Xiu, Song Qi. New book of Tang Dynasty: Volume 97, biography 22, Wei Zheng [M]. Beijing: Zhonghua Book Company, 1975:3880 